\title{
EFFECTS OF TREATMENT WITH TRICHODERMA HARZIANUM AND SOME PLANT ACTIVATORS ON POST-HARVEST DECAY OF APPLE BLUE MOLD (PENICILLIUM EXPANSUM LINK.) AND BROWN ROT (MONILINIA FRUCTIGENA HONEY EX WHETZEL)
}

\author{
YILDIZ, C. ${ }^{1}-$ COSKUNTUNA, A. ${ }^{2 *}$ \\ ${ }^{1}$ Istanbul Directorate of Provinical Agriculture and Forestry, Ministry of Agriculture and \\ Forestry, Rebuplic of Turkey, 34728 Kadikoy, Istanbul, Turkey \\ (e-mail: cihan.yildiz@tarimorman.gov.tr; phone: +90-216-468-2100) \\ ${ }^{2}$ Department of Plant Protection, Agriculture Faculty, Tekirdag Namik Kemal University, \\ 59030 Tekirdag, Turkey \\ *Corresponding author \\ e-mail: acoskuntuna@nku.edu.tr phone: +90-282-250-2083 \\ (Received 25 $5^{\text {th }}$ Apr 2019; accepted $2^{\text {nd }}$ Jul 2019)
}

\begin{abstract}
The post-harvest application of Trichoderma harzianum proved to be effective in the control of blue mold and brown rot on apple. The possibilities of separately application of harpin protein (hp) and Lactobacillus acidophilus's fermentation product (Lafp) and boscalid+pyraclostrobin fungicide were evaluated to the shelf-life of apples. TRIC8 and the plant activators applied to the fruits one hour before pathogens inoculations. The apples were inoculated with a micropipette via the artificially created wounds with the pathogens $P$. expansum and $M$. fructigena with suspensions of $1 \times 10^{6}$ conidia/mL $\mathrm{mL}^{-1}$. After one hour the pathogens inoculations, the fungicide was sprayed onto the fruits at recommended dosage. The apples were stored at $\left(22 \pm 2^{\circ} \mathrm{C}\right)$ for ten days. TRIC8 was reduced lesion diameter of $P$. expansum and M. fructigena by $69.73 \%$ and $97.13 \%$ respectively. Significant results on brown rot was provided by the application of Lafp (100\%) but not had same success on blue mold (29.59\%). Hp was provided to reduction of lesion diameter on blue mold and brown rot at $29.76 \%$ and $41.65 \%$, respectively. The fungicide demonstrated $37.22 \%$ and $100 \%$ control of blue mold and brown rot on the apples in the shelf-life study, respectively.
\end{abstract}

Keywords: apple, biological control, blue mold, brown rot, harpin protein, Lactobacillus acidophilus, post-harvest

\section{Introduction}

Apple (Malus domestica) is an economically important crop in Turkey. According to 2017 data, there were produced 3.032164 tons of apple in the field of 175.357 ha in Turkey (FAOSTAT, 2017). The rate of loss of fresh fruits and vegetables after harvest is $25 \%$ in developed countries; however, it can increase to $50 \%$ in developing countries (Salunkhe and Kadam, 1998). Fruits and vegetable continue to physiological events such as respiration, sweating, and ethylene production after the harvest. In storage as well, fruits that continue physiological activities like respiration, transpiration, and so on, are exposed to activities of fungal pathogens present in the environment, as well as to biochemical and physical changes. Pathogen fungi cause postharvest disease are usually passive pathogens that can only entrance into wounds on fruit. The fruit are susceptible to the decay caused by several pathogenic fungi including Penicillium sp., Geotrichum sp., Rhizopus sp., Phytophthora sp., Monilinia sp. and Botrytis sp. (Barad, 2016; Benli, 2003; Errampalli et al.,2004; 2005; Fiori et al., 2008; Chávez et al., 2014). 
More than 90 fungal pathogen species have been reported as causal agents in apple decay during storage (Jones and Aldwinckle, 1990).

To control blue mold disease caused by $P$. expansum, is the most common wound pathogen during harvest, transport and storage. So, store should be cleaned, ventilated, disinfected before the fruits are stored, and excessive humidity should be avoided (Ozgonen and Kilic, 2013). Little is known about to mechanism used to decay of caused by $P$. expansum on apple. The secretion of pectolytic enzymes have an important role on pathogenicity. On the other hand patulin known as secondary toxic metabolite that produce by blue mold (Morales et al., 2010; Barad et al., 2016; Snini et al., 2016). $M$. fructigena is a common species of Monilinia found on apples and pears in Europe, and is commonly referred to as "apple brown rot" (Jones and Aldwinckle, 1990; Leeuwen et al., 2002). Of pome fruits, apple and pear are sensitive to brown rot disease caused by M. fructigena, and of stone fruits, plum is sensitive to brown rot disease (Byrde and Willets, 1977). M. fructigena has been reported to infect in more than 40 hosts. These include apples, pears, quince, apricots, peaches, plums and cherries (Sagasta, 1977). Post-harvest disease control is achieved by the use of synthetic fungicides such as sodium ortho-phenylphenate, imazalil or thiabendazole (Penrose et al., 1989; Yildiz et al., 2005). Use of the fungicides provides satisfactory control against mold infection. But fungicidal residues can have harmful effect on people and environment. The global trend appear to reduced use of fungicides on produce and demand for reducing disease loss in the harvested commodities (Sharma et al., 2009). So, development of alternative control possibilities has become very important because of the need to reduce the use of fungicides, their residues, concerns about human health and environmental pollution, and development of fungicide-resistant strains for pathogenic fungi (Capdeville et al., 2002; Calvo et al., 2017). Nowadays the researches on using biocontrol agents and alternative chemicals and hot-water treatments on postharvest diseases have been increasing (Falconi and Mendgen, 1994; Janisiewicz et al., 1994; Hong et al., 1998; Ippolito, 1998; Benli, 2003; Li and Yu, 2000; Karabulut et al., 2002; Capdeville et al., 2002, 2003; Irina et al., 2006; Wang et al., 2008; Fiori et al., 2008; Manso and Nunes, 2011; Amiri and Bompeix, 2011; Hasssam et al., 2011; Mari et al., 2012; Zhao et al., 2012; Li et al., 2015; Yaseen et al., 2015; Zhu et al., 2016; Kabelitz et al., 2018). Some antagonistic yeasts such as Candida sake Satio \& Ota, $C$. oleaphila Montrocher, $C$. saitona Nakase \& Sutuki, were used to controlling decay of apple and pear caused by $B$. cinerea Pers.: Fries and P. expansum Link. (Sharma et al., 2009). Bacteria as antagonist biological control agents such as Bacillus amyloliquefaciens BUZ-14 and Aureobasidium pullulans and Pseudomonas fluorescens have been used against blue mold in apples (Vinas et al., 1998; Ippolito et al., 2000; Mari et al., 2012; Calvo et al., 2017; Wang et al., 2018).

The aim of the study the control possibilities of blue mold disease caused by $P$. expansum and brown rot caused by $M$. fructigena, with $T$. harzianum (TRIC8), harpin protein (hp), Lactobacillus acidophilus's fermentation product (Lafp), and with boscalid+pyraclostrobin was evaluated to extend the self life of the apples.

\section{Materials and methods}

\section{Fruit}

Granny Smith apple cultivars not treated with pesticides were harvested in Tekirdag Viticulture Research Institute orchards, Turkey. Healthy fruits were selected without 
physical injuries. The apples were surface disinfected with $70 \%$ ethanol and rinsed in sterile distilled water (SDW), dried at room temperature $\left(24^{\circ} \mathrm{C}\right)$.

\section{Pathogens and antagonist isolates}

In the study, $P$. expansum was isolated from decayed apples and other pathogen isolate $M$. fructigena (MON14) and biological control antagonist isolate T. harizanum (TRIC8, Accession number: MH351669) were provided by Prof. Dr. Nuray Ozer, Tekirdag Namik Kemal University, Agricultural Faculty, Department of Plant Protection.

\section{Postharvest treatments of apples}

$P$. expansum isolate and T. harzianum TRIC8 antagonist isolate were grown on potato dextrose agar (PDA) and incubated at $24{ }^{\circ} \mathrm{C}$ for 7 days. Petri dishes containing vegetable juice agar (V8 agar) was inoculated with $M$. fructigena isolate (MON14) and incubated at $24^{\circ} \mathrm{C}$ for 10 days. The concentration of the P. expansum and M. fructigena were adjusted to $1 \times 10^{6}$ conidia/ $\mathrm{mL}^{-1}$ with the aid of a thoma slide. Artificial wounds were performed using sterile needle to make $2 \mathrm{~mm}$ deep and $2 \mathrm{~mm}$ wide wounds (two wounds for each the apple) along the fruit equatorial areas. Spore suspension of $T$. harzianum (TRIC8) was counted with a thoma slide and adjusted to concentration $1 \times 10^{8}$ conidia $/ \mathrm{mL}^{-1}$. Firstly, each wound on apple was inoculated with $20 \mu \mathrm{L}$ drop of $1 \times 10^{8}$ conidia $/ \mathrm{mL}^{-1}$ of TRIC8 and left for incubation at room temperature $\left(22 \pm 2{ }^{\circ} \mathrm{C}\right)$ for one hour. After one hour, the apples treated with TRIC8 were inoculated with a micropipette into the wounded points with $20 \mu \mathrm{L}$ drop of $1 \times 10^{6}$ conidia/ $\mathrm{mL}^{-1}$ of the pathogens.

$1 \%$ Harpin protein (Hp) (WDG formulation, Eden Bioscience Co.; Messenger Gold, $12 \mathrm{~g} / 100 \mathrm{l}$ water) (Wang et al., 2008). Lactobacillus acidophilus's fermentation product (Lafp) (Alltech Crop Science; ISR 2000; $100 \mathrm{ml} / \mathrm{da}$ ) (Boyraz et al., 2006). Hp and Lafp plant activators were dissolved in SDW and then sprayed with commercial dosage to fruits one hour before pathogens inoculations.

However, to compare the results of chemical reactions with T. harzianum and plant activators, the test fungicide $25.2 \%$ boscalid $+12.8 \%$ pyraclostrobin $\left(\right.$ Basf $^{\mathbb{R}}$, Bellis WG; $50 \mathrm{~g} / 100 \mathrm{l}$ water) was applied with the commercial dose by spraying one hour after the inoculation of the pathogens. To maintain humidity environment, two wet papers were placed in each plastic box was wrapped in an unsealed $0.05 \mathrm{~mm}$ polyethylene bag. The development of the diseases were determined by measuring the lesion diameters of decay on apples inoculated with $10^{6}$ spores $\mathrm{mL}^{-1}$ pathogens inoculum and incubated for 10 days at $24{ }^{\circ} \mathrm{C}\left(22 \pm 2{ }^{\circ} \mathrm{C}\right)$. Mean lesion diameter was calculated at the end of the study. Non-inoculated with the pathogens: $20 \mu \mathrm{l}$ drop Sterile Distilled Water (SDW) was used only for each wound on apple in our study as negative control. Each treatment was independently performed two times with five replicate fruit; in each experiment twenty fruit per treatments were included.

We used to the effectiveness of the applications was calculated using Abbott's formula (Abbott, 1925; $E q$ 1):

$$
\% \text { effectiveness }=[(\mathrm{Ic}-\mathrm{It}) / \mathrm{Ic}] \times 100
$$


Where: Ic is the disease diameter of the untreated control (+), It is the disease diameter of the treatment.

\section{Statistical analysis}

At the end of the storage period, the severity of the diseases was determined by the mean lesion diameter in millimetre on the rotted apples. Statistical significance was judged at level $P \leq 0.05$. When the analysis was statistically significant, the Duncan multiple comparison test was used for means separation. SPSS (Statistical Package for Social Sciences, Inc., 2001, Model 11.0 Chicago) was used analysis program.

\section{Results}

The results of this study demonstrated that post-harvest applications of the TRIC8 significantly controlled blue mold caused by $P$. expansum on apple at the rate of $69.73 \%$. This effect was found to be significant at $P \leq 0.05$ level. While the mean lesion diameter of $P$. expansum growth of untreated apples was $5.90 \mathrm{~cm}$, the apples treated with TRIC8 had $1.79 \mathrm{~cm}$, at $10^{\text {th }}$ day. The mean lesion diameters of the hp and Lafp treated apples were $4.14 \mathrm{~cm}$ and $4.16 \mathrm{~cm}$, respectively, with both plant activators being equally effective $(\square 29.00 \%)$ in reducing decay. The control of blue mold by boscalid+pyraclostrobin indicates that is not highly effective (37.22\%) against the sporulation of P. expansum in the self-life condition (Table 1; Fig. 1).

Table 1. Effects of treatments on lesion development of P. expansum on apple fruits

\begin{tabular}{c|c|c}
\hline Treatments & Lesion diameter $(\mathbf{c m})$ & Effect $(\%)$ \\
\hline Inoculated control & $5.90 \mathrm{a}$ & $0.00 \mathrm{c}$ \\
T. harzianum TRIC8 & $1.79 \mathrm{c}$ & $69.73 \mathrm{a}$ \\
hp & $4.14 \mathrm{~b}$ & $29.76 \mathrm{~b}$ \\
Lafp & $4.16 \mathrm{~b}$ & $29.59 \mathrm{~b}$ \\
B+p (fungicide) & $3.56 \mathrm{~b}$ & $37.22 \mathrm{~b}$ \\
\hline
\end{tabular}

Means of treatment within the same column followed by different letters are significantly $(\mathrm{P} \leq 0.05)$ different according to Duncan's multiple range test.
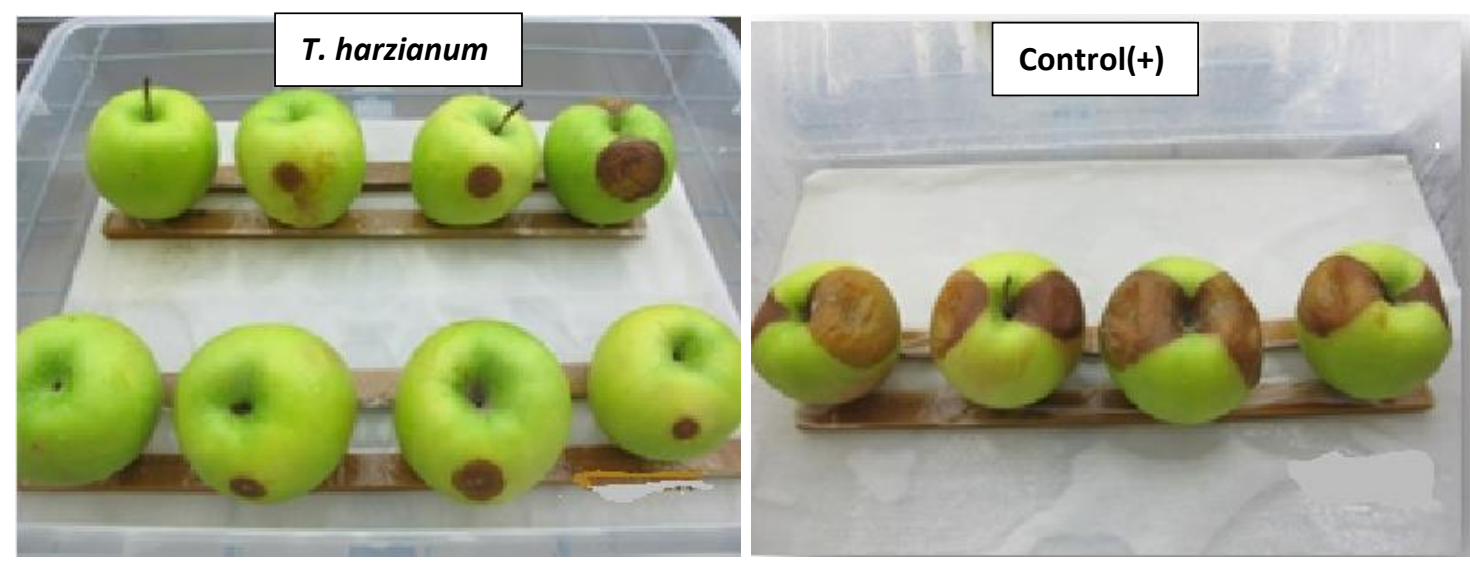

Figure 1. Biocontrol activity of T. harzianum TRIC8 in inhibiting blue mold caused by $P$. expansum on apples 
The results show that TRIC8 is also effective on the mean lesion diameter of $M$. fructigena on apple. While the mean lesion diameter of $M$. fructigena growth of untreated apples was $7.50 \mathrm{~cm}$, the apples treated with TRIC 8 had $0.21 \mathrm{~cm}$, at $10^{\text {th }}$ day. The effect of TRIC8 treatment on brown rot was calculated as $97.13 \%$. This value was significantly as statistically $(\mathrm{P} \leq 0.05)$. The mean lesion diameters of the hp and Lafp treated apples were $4.23 \mathrm{~cm}$ and $0.00 \mathrm{~cm}$, respectively. Lafp treatment had a significantly greater effect $(100 \%)$ in reducing decay than hp $(41.65 \%)$ treatment (Table 2) (Fig. 2) $(P \leq 0.05)$.

Table 2. Effects of treatments on lesion development of M. fructigena on apple fruits

\begin{tabular}{c|c|c}
\hline Treatments & Lesion diameter $(\mathbf{c m})$ & Effect $(\boldsymbol{\%})$ \\
\hline Inoculated control & $7.50 \mathrm{a}$ & $0.00 \mathrm{c}$ \\
T. harzianum TRIC8 & $0.21 \mathrm{~b}$ & $97.13 \mathrm{a}$ \\
hp & $4.23 \mathrm{~b}$ & $41.65 \mathrm{~b}$ \\
Lafp & $0.00 \mathrm{c}$ & $100.00 \mathrm{a}$ \\
B+p (fungicide) & $0.00 \mathrm{c}$ & $100.00 \mathrm{a}$ \\
\hline
\end{tabular}

Means of $M$. fructigena lesions diameter within each column followed by different at $(\mathrm{P} \leq 0.05)$ according to Duncan's multiple range test.
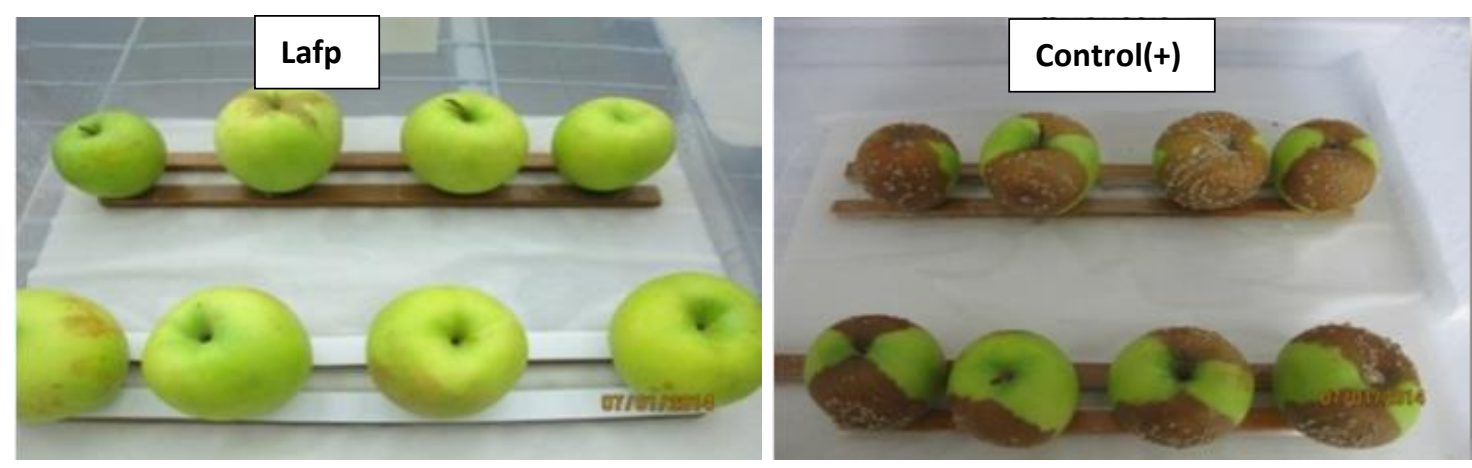

Figure 2. Plant activator of Lafp in inhibiting brown rot caused by M. fructigena on apples

Significant differences $(\mathrm{P} \leq 0.05)$ were obtained in $M$. fructigena lesion diameters on wounded the apples when treated with the $\mathrm{B}+\mathrm{p}$ compared to the treatment with only inoculated $M$. fructigena on the apple (Table 2).

\section{Discussion}

T. harzianum TRIC8 treatment had a significantly greater effect in reducing decay caused by $M$. fructigena than either decay caused by $P$. expansum. The effectiveness of TRIC8 against both blue mold and brown rot of apple were significantly statistically $(\mathrm{P} \leq 0.05)$. TRIC8 isolate of $T$. harzianum proved its antagonistic potential in controlled reducing blue mold and brown rot on Grany Smith apple cultivars. When the apple treated with TRIC8, demonstrated postharvest pathogens of fruit has the ability to be efficient at $1 \times 10^{8}$ conidia/ $\mathrm{mL}^{-1}$ concentration. In apples, Batta (2004) observed low effect $(48.8 \%)$ of formulated $T$. harzianum against the blue mold on apple is 
significantly attributed to the antagonistic effect of $T$. harzianum but not to because of the formulation ingredients.

Preliminary studies show that different active ingredients with fungicide; such as benomyl, captan, carbendazim, iprodione, mancozeb, myclobutanil, procymidone, thiram, thiophanate methyl, triforin, vinclozolin, and prochloraz etc., were effective to control of $P$. expansum during preharvest and postharvest. Since noticed of thiabendazole resistant blue mold in apple packing houses, study for alternative chemical control strategies have increased greatly (Eckert and Ogawa, 1988; Biyk et al., 1994; Li and Yu, 2000; Moreira and Mio, 2007; Feliziani et al., 2012).

Boscalid + pyraclostrobin active ingredients with fungicide against $M$. fructigena on apples that is only applied postharvest. Also, brown rot was reduced by $100 \%$ in apple fruit postharvest with this fungicide in this study. The same fungicide was able to mycelial growth of $P$. expansum on apple. But, this fungicide was effective when applied 7 or 14 days before harvest and reduced blue mold incidence by 41 to $70 \%$ (Xiao and Boal, 2009).

Harpin protein and L. acidophilus fermentation product elicitors of systemic acquired resistance in the host tissue that could indirectly help to protect apples from pathogens. The effect of application of harpin protein on the apples was less effective against blue mold and brown rot in this study. Capdeville et al. used to Hp in pre and postharvest treatments of apples induced resistance to $P$. expansum on apple. When they inoculated with the concentration $1 \times 10^{4}$ conidia/ $\mathrm{mL}^{-1} P$. expansum on apple in hp treatment a few days (4-8 days) before harvest was even more effective than the presented study (Capdeville et al., 2002, 2003).

Lafp had successfully controlled the brown rot caused by M. fructigena on apple in the present study. Similarly, the control of blue mold and grey mold on apple with Acibenzolar-S- methyl was reported before (Spadaro et al., 2004). $\beta$-aminobutyric-acid (BABA) on the activation of resistance responses in apple was investigated by Quaglia et al. (2017). Conversely, BABA resistance was not effective in the control of blue mold on apple such as Lafp.

Successful results similar to our study were obtained concerning the prevention of disease with Trichoderma spp. against $M$. fructicola on peaches and plums in the study of Hong et al. (1998) and with Trichoderma polysporum against M. fructigena on apples. The antagonist fungus $T$. polysporum, which was isolated from the apple leaves, was found to inhibit B. cinerea at $93 \%$, M. fructigena at $80 \%$, and P. expansum at $87 \%$ in postharvest apples (Falconi and Mendgen, 1994).

Aureobasidium pullulans, Candida infirmominiatus, C. laurentii, Rhodotourula spp, M. pulcherrima, and Pichia angust, from the yeasts isolated from the surface of the fruit, leaves and flowers, were found to be successful to prevent the disease, preharvest and postharvest in addition to T. harzanium that we applied in the biological control of post-harvest brown rot (Falconi and Mendgen, 1994; Chand and Spots, 1995; Hong et al., 1998; Irina et al., 2006; Fiori et al., 2008). As for our study, a similar effect was achieved $(\sim 70 \%)$ as the biological control agent $T$. harzianum successfully controlled $P$. expansum (Falconi and Mendgen, 1994). When the lesions were measured for the different postharvest fruits (pear, grape and kiwi) that were treated with the $T$. harzianum emulsion was found to support our research results (Batta, 2006).

In the biological control of $P$. expansum in the postharvest apples, different Trichoderma spp. (T. atrovide), apart from $T$. harzianum, also were found to have successful decay inhibition ranged of $35-50 \%$ while Pseudomonas syringae isolates and 
P. agglomorates were found to be $100 \%$ and $81 \%$ effective, respectively. This may be attributed to the different action mechanisms of antagonist bacteria (Nunes et al., 2002; Quaglia et al., 2010).

Yeast-based and bacteria antagonist isolates isolated from the fruit surface of apples, leaves, flowers and soils such as Sporobolomyces roseus, Aureobasidium pullulans, Metschnikowia andauensis, Candida sake, Cryptococcus in firomo-miniatus, $C$. laurentii, Hanseniaspora uvarum, Rhodotourula spp. and Bacillus amyloliquefaciens BUZ-14 have also been successfully applied to the postharvest biologic control of $P$. expansum (Janisiewicz et al., 1994; Leibinger et al., 1997; Ippolito et al., 2000; Nunes et al., 2002; Karabulut et al., 2002; Turkekul, 2003; Spadaro et al., 2004; Manso and Nunes, 2011; Calvo et al., 2017).

There was no study to treatment of the apples with Lafp against $P$. expansum postharvest. However, 14 days and 21 days before the harvest, Lafp plant activator was applied to oranges, followed by the inoculation of $P$. digitatum $\left(1 \times 10^{6}\right.$ conidia/ $\left.\mathrm{mL}^{-1}\right)$. The reported $50 \%$ success rate as a result of the application of plant activator to the fruit 21 days before pathogen application was more effective than our work. In this study as well, in stimulating durability against disease, it is inferred that the time period after the application of the plant activator should be long (Bower, 2007).

The effective results obtained in this research will contribute to the expansion of the usage areas of plant activators that do not harm human health and the environment. It is thought that promising results can be obtained for different pathogens with different combinations of applications of Lafp and T. harzianum, which have been successfully used individually.

\section{Conclusion}

Biological control with antagonist fungi have been a promising alternative, with lower environmental effect, either alone or as part of integrated pest management to reduce synthetic fungicide usage in postharvest diseases of fruit and vegetables for many years. The present results indicate that $T$. harzianum (TRIC8) has potential as a biocontrol agent for the control of postharvest decay of apple caused by $P$. expansum and $M$. fructigena. TRIC8 treatment was used to control of $M$. fructigena more effective than $P$. expansum on apple and could become an alternative to fungicide in postharvest decay control of brown rot on apple, but registration and development investigations to acquire a commercial product are needed.

Acknowledgements. This study was supported with financial by Namik Kemal University (NKU_BAP.00.24.YL.13.04), Scientific Research Project Community.

\section{REFERENCES}

[1] Abbott, W. S. (1925): A method of computing the effectiveness of an insecticide. - J. Econ. Entomol. 18: 265-267.

[2] Amiri, A., Bompeix, G. (2011): Control of Penicillium expansum with potassium phosphite and heat treatment. - Crop Protection 30: 222-227.

[3] Barad, S., Espeso, E. A., Sherman, A., Prusky, D. (2016): Ammonia activates pacC and patulin accumulation in an acidic environment during apple colonization by Penicillium expansum. - Molecular Plant Pathology 17(5): 727-740. DOI: 10.1111/mpp.12327. 
[4] Batta, Y. A. (2004): Effect of treatment with Trichoderma harzianum Rifai formulated in invert emulsion on postharvest decay of apple blue mold. - International Journal of Food Microbiology 96: 281-288.

[5] Batta, Y. A. (2006): Control of postharvest diseases of fruit with an invert emulsion formulation of Trichoderma harzianum Rifai. - Postharvest Biology and Technology 43: 143-150.

[6] Benli, M. (2003): Hyperparasitic effect of epiphytic yeasts on Penicillium expansum and Botrytis cinerea hyphae. - Orlab On-Line Microbiology Journal 1(5): 1-9.

[7] Biyk, H., Wojtas-Koziel, B., Lewandowska, M., Rejnus, M. (1994): Fungi causing apple diseases in storage and their control with several fungicides. - Review of Plant Pathology 73(7): 4522.

[8] Bower, J. P. (2007): The use of isr 2000 as an aid bio control of postharvest decay in citrus. - https://en.engormix.com/agriculture/articles/isr-2000-aid-biocontrol-t33873.htm (accessed on 24.04.2019).

[9] Boyraz, N., Kaymak, S., Baştaş, K. K. (2006): Effects of some plant activators and their combinations with fungicides against apple scab disease (Venturia inaequalis (CKE) WINT.) - Journal of Selcuk Agriculture Faculty 20(39): 1-6.

[10] Byrde, R. J. W., Willets, H. J. (1977): The Brown Rot Fungi of Fruit Their Biology and Control. - Pergamon Press, Oxford, UK.

[11] Calvo, H., Marco, P., Blanco, D., Oria, R., Venturini, M. E. (2017): Potential of a new strain of Bacillus amyloliquefaciens BUZ-14 as a biocontrol agent of postharvest fruit diseases. - Food Microbiology 63: 101-110.

[12] Capdeville, G., Beer, G., Watkins, V., Wilson, C. B., Tedeschi, L. O., Aist, J. R. (2003): Pre and post-harvest harpin treatments of apples induce resistance to blue mold. - Plant Diseases 87: 39-44.

[13] Capdeville, G., Wilson, C. L., Beer, S. V., Aist, J. R. (2002): Alternative disease control agents induce resistance to blue mold in harvested 'red delicious' apple fruit. Phytopathology 92: 900-908.

[14] Chand, G. T., Spotts, R. A. (1995): Postharvest biological control of blue mold and brown rot on sweet cherry by natural saprophytic yeast alone or in combination with low doses of fungicides. - Biological Control 6: 253-259.

[15] Chávez, R. A. S., Peniche, R. Á. M., Medrano, S. A., Munoz, L. S., Ortíz, M. del S. C., Espasa, N. T., Sanchis, R. T. (2014): Effect of maturity stage, ripening time, harvest year and fruit, characteristics on the susceptibility to Penicillium expansum link of apple genotypes from Queretaro, Mexico. - Scientia Horticulturae 180: 86-93.

[16] Eckert, J. W., Ogawa, J. M. (1988): The chemical control of post harvest diseases: deciduous fruits, berries, vegetables and root/tuber crops. - Annual Review of Phytopathology 26: 433-469.

[17] Errampalli, D. (2004): Effect of fludioxonil on germination and growth of Penicillium expansum and decay in apple cvs. Empire and Gala. - Crop Protection 23: 811-817.

[18] Errampalli, D., Northover, J., Skog, L., Brubacher, N. R., Collucci, C. A. (2005): Control of blue mold (Penicillium expansum) by fludioxonil in apples (cv Empire) under controlled atmosphere and cold storage conditions. - Pest Management Science 61: 591596 DOI: 10.1002/ps.1010.

[19] Falconi, C. J., Mendgen, K. (1994): Epiphytic fungi on apple leaves and their value for control of the post harvest pathogens Botrytis cinerea, Monilinia fructigena, Penicillium expansum first publ in: - Zeitschrift Pflanzenkrankheiten und Pflanzenschutz 101: 38-47.

[20] FAOSTAT (2017): 2017 data. - faostat.fao.org/site/339/default.aspx.

[21] Feliziani, E., Santini, L., Landi, L., Romanazzi, G. (2012): Pre and postharvest treatment with alternatives to synthetic fungicides to control postharvest decay of sweet cherry. Postharvest and Biotechnology 78: 133-138. 
[22] Fiori, S., Fadda, A., Giobbe, S., Berardi, E., Migheli, Q. (2008): Pichia angusta is an effective biocontrol yeast against postharvest decay of apple fruit caused by Botrytis cinerea and Monilia fructicola. - FEMS Yeast Res 8: 961-963.

[23] Haissam, J. M. (2011): Pichia anomala in biocontrol for apples: 20 years of fundamental research and practical applications. - Antonie van Leeuwenhoek 99: 93-105. DOI: 10.1007/s10482-010-9541-2.

[24] Hong, C., Michailides, J., Holtz, B. A. (1998): Effects of wounding, inoculum density and biological control agents on postharvest brown rot of stone fruits. - Plant Disease 82: 1210-1216.

[25] Ippolito, A., Ghaouth, A. E., Wilson, C. L., Wisniewski, M. (2000): Control of postharvest decay of apple fruit by Aureobasidium pullulans and induction of defense responses. - Postharvest Biology and Technology 19: 265-272.

[26] Irina, G., Cornea, C. P., Mateescu, R., Olteanu, V., Voaides, C. (2006): Control of postharvest fruit rot in apricot and peach by Methschikowia pulcherrima. - Buletin USAMV-CN 62: 74-79.

[27] Janisiewicz, W. J., Peterson, D. L., Bors, R. (1994): Control of storage decay of apple with Sporobolomyces roseus. - Plant Disease 78: 466-470.

[28] Jones, A. L., Aldwinckle, H. S. (1990): Brown Rot Diseases. Compendium of Apple and Pear Diseases. - American Phytopathology Society Press, USA.

[29] Kabelitz, T., Hassenberg, K. (2018): Control of apple surface microflora for fresh-cut produce by post-harvest hot-water treatment. - LWT - Food Science and Technology 98 492-499.

[30] Karabulut, O. A., Coohen, L., Wiess, B., Daus, A., Lurie, S., Droby, S. (2002): Control of brown rot and blue mold of peach and nectarine by short hot water brushing and yeast antagonists. - Postharvest Biology and Technology 24: 103-111.

[31] Leeuwen, G. C. M., Baayen, R. P., Holb, I. J., Jeger, M. J. (2002): Distinction of the Asiatic brown rot fungus Monilinia polystroma sp. Novfrom M. fructigena. Mycological Research 100: 444-451.

[32] Leibinger, W., Breuker, B., Hahn, M., Mendgen, K. (1997): Control of postharvest pathogens and colonization of apple surface by antagonistic microorganism in the field. Phytopathology 97: 1103-1110.

[33] Li, H., Yu, T. (2000): Effects of chitosan on incidence of brown rot, quality and physiological attributes of postharvest peach fruit. - Journal of the Science of Food and Agriculture 81: 269-274.

[34] Li, Q., Wu, L., Hao, J., Luo, L., Cao, Y., Li, J. (2015): Biofumigation on post-harvest diseases of fruits using a new volatile-producing fungus of Ceratocystis fimbriata. PLoS ONE 10(7): e0132009. DOI: 10.1371/journal.pone.0132009.

[35] Manso, T., Nunes, C. (2011): Metschnikowia andaunensis as a new biocontrol agent of fruit postharvest diseases. - Postharvest Biology and Technology 61: 64-71.

[36] Mari, M., Martini, C., Spadoni, A., Rouissi, W., Bertolini, P. (2012): Biocontrol of apple postharvest decay by Aureobasidium pullulans. - Postharvest Biology and Technology 73: $56-62$.

[37] Morales, H., Marín, S., Ramos, A. J., Sanchis, V. (2010): Influence of post-harvest technologies applied during cold storage of apples in Penicillium expansum growth and patulin accumulation: a review. - Food Control 21: 953-962.

[38] Moreira, L. M., Mio, de L. L. M. (2007): Control of peach tree brown rot by fungicides and phosphites evaluated during preharvest and postharvest. - Cienc. Agrotec. Lavras 33(2): 405-411.

[39] Nunes, C., Usall, J., Teixido, N., Fons, E., Viñas, I. (2002): Post-harvest biological control by Pantoea agglomerans (CPA-2) on golden delicious apples. - Journal of Applied Microbiology 92: 247-255.

[40] Ozgonen, H., Kilıc, C. H. (2013): Apple and Pear Postharvest Diseases. - Hasat Publishing, Istanbul, Turkey, pp. 25-26. 
[41] Penrose, L. J., Koffman, W., Ridings, H. I. (1989): Factors affecting the efficacy of postharvest fungicide applications for the control of blue mold (Penicillium expansum) in stored apples. - Plant Pathology (1989): 421-426.

[42] Quaglia, M., Baglivo, F., Moretti, C. (2017): Postharvest $\beta$-aminobutyric-acide-primed resistance is not effective in the control of Penicillium expansum Link. on 'Golden delicious' apple fruit. - Crop Protection 102: 43-48.

[43] Quaglia, M., Ederli, L., Pasqualini, S., Zazzerini, A. (2010): Biological control agents and chemical inducers of resistance for postharvest control of Penicillium expansum link. on apple fruit. - Postharvest Biology and Technology 59: 307-315.

[44] Sagasta, E. M. (1977): Monilinia diseases. - EPPO Bulletin 7: 105-116.

[45] Salunkhe, D. K., Kadam, S. S. (1998): Handbook of Vegetable Science and Technology: Production, Composition, Storage and Processing. Vol. 1. Introduction. - CRC, Boca Raton, FL, pp. 1-10.

[46] Sharma, R. R., Singh, D., Singh, R. (2009): Biological control of postharvest diseases of fruits and vegetables by microbial antagonists: a review. - Biological Control 50: 205221.

[47] Snini, S. P., Tannous, J., Heuillard, P., Bailly, S., Lippi, Y., Zehraoui, E., Barreau, C., Oswald, I. P., Puel, O. (2016): Patulin is a cultivar-dependent aggressiveness factor favouring the colonization of apples by Penicillium expansum. - Molecular Plant Pathology 17(6): 920-930.

[48] Spadaro, D., Garibaldi, A., Gullino, M. L. (2004): Control of Penicillium expansum and Botrytis cinerea on apple combining a biocontrol agent with hot water dipping and acibenzolar-S-methyl, baking soda, or ethanol application. - Postharvest Biology and Technology 33: 141-151.

[49] Turkekul, S. (2003): Research on the biological control of postharvest diseases Penicillium expansum and Botrytis cinerea on apples. - MSc. Thesis, Aegean University, Agricultural Faculty, Department of Plant Protection, Izmir, Turkey, 60p.

[50] Vinas, I., Usall, J., Teixido, N., Sanchis, V. (1998): Biological control of major postharvest pathogens on apple with Candida sake. - International Journal of Food Microbiology 40: 9-16.

[51] Wang, H., Jiang, M., Chen, K., Wang, K., Du, M., Zalan, Z., Hegyi, F., Kan., J. (2018): Biocontrol of Penicillium digitatum on postharvest citrus fruits by Pseudomonas fluorescens. - Hindawi Journal of Food Quality, Article ID 2910481. https://doi.org/10.1155/2018/2910481.

[52] Wang, Y., Li., X., Bi, Y., Ge, Y., Li, Y., Xie, F. (2008): Postharvest ASM or Harpin treatment induce resistance of muskmelons against Trichothecium roseum. - Agricultural Sciences in China 7(2): 217-223.

[53] Xiao, K., Boal, R. J. (2009): A preharvest application of pyraclostrobin and boscalid for control of postharvest grey mold and blue mold in apples. - Plant Diseases 93: 185-189.

[54] Yaseen, T., Ricelli, A., Turan, B., Albanese, P., D'onghia, M. M. (2015): Ozone for postharvest treatment of apple fruits. - Phytopathologia Mediterranea 54(1): 94-103. DOI: 10.14601/Phytopathol_Mediterr-14478.

[55] Yildiz, F., Kinay, P., Yildiz, M., Sen, F., Karacali, I. (2005): Effects of preharvest applications of $\mathrm{CaCl}_{2}, 2,4-\mathrm{d}$ and benomyl and postharvest hot water, yeast and fungicide treatments on development of decay satsuma mandarins. - J. Phytopathology 153: 94-98.

[56] Zhao, Li., Zhang, H., Lin, H., Zhang, X., Ren, X. (2012): Effect of trehalose on the biocontrol efficacy of Pichia caribbica against post-harvest grey mould and blue mould decay of apples. - Pest Management Science 69: 983-989.

[57] Zhu, Y. Yu, J., Brecht, J. K., Jiang, T., Zheng, X. (2016): Pre-harvest application of oxalic acid increases quality and resistance to Penicillium expansum in kiwifruit during postharvest storage. - Food Chemistry 190: 537-543. 